\title{
Elektrokonvulsiv terapi - virkninger og bivirkninger
}

\author{
Sammendrag \\ Bakgrunn. Ved elektrokonvulsiv terapi \\ (ECT) er det usikkerhet knyttet til grad \\ av effekt og varighet av bivirkninger. Vi \\ ville undersøke indikasjoner, effekt, tid \\ til bedring og bivirkninger.
}

\begin{abstract}
Materiale og metode. ECT-protokollene og pasientjournalene ved tre psykiatriske avdelinger ved Dikemark sykehus i perioden 1960-95 ble systematisk gjennomgått.
\end{abstract}

Resultater. 141 personer fikk 241 behandlingsserier og til sammen 1960 behandlinger. Alvorlig depresjon var hoveddiagnose hos 124 (88\%). Før ECTterapien var 129 (91\%) behandlet med minst ett antidepressivum, 107 (76\%) med minst to ulike antidepressiver og 67 (48\%) fra to ulike klasser uten tilfredsstillende klinisk bedring av aktuell depresjonsepisode. Litium ble i forkant brukt av 31 (22\%). Innen fire uker etter første ECT-behandling ble tilstanden hos $120(85 \%)$ av pasientene vurdert som bedret. 61 av disse oppnådde remisjon og kunne utskrives innen fire uker. Første tegn på bedring etter første serie var notert for 92 pasienter. 71 (77\%) viste bedring innen seks dager. Etter 123 av totalt 241 serier ( $51 \%$ ) ble det registrert bivirkninger. Fem pasienter fikk alvorlige komplikasjoner.

Fortolkning. Den umiddelbare effekten av ECT-behandling var god, og bedringstegnene kom hos de fleste den første uken. Det var tendens til best respons ved psykotisk depresjon og høy alder. Tatt i betraktning pasientgruppens svært alvorlige og langvarige sykdom, var behandlingen relativt sikker og ble godt tolerert.

\author{
Kjell Martin Moksnes \\ kjellmartin.moksnes@ulleval.no \\ Alderspsykiatrisk avdeling \\ Klinikk psykisk helse og avhengighet \\ Oslo universitetssykehus \\ Slottsberget 35 \\ 1385 Asker
}

\section{Stein Opjordsmoen Ilner}

Avdeling for forskning og undervisning

Klinikk psykisk helse og avhengighet

Oslo universitetssykehus

Elektrokonvulsiv terapi (ECT) har gjennom 70 år dokumentert god effekt ved akutt behandling av alvorlig depresjon (1). Behandlingen er erfaringsbasert, og virkningsmekanismen har vært usikker, men nyere forskning viser økning av nervecellevekstfaktorer og økning av hippocampusvolumet (2). Terapien er stadig blitt modifisert for å redusere akutte bivirkninger, mens langtidsbivirkninger først er blitt dokumentert $i$ den senere tid $(3,4)$. Etter 1958 trodde mange at bruk av denne type behandling ville opphøre ettersom kvalifisert samtalebehandling og nye legemidler overtok som hovedbehandlingsmetoder sammen med miljøterapi og sosialpsykiatriske tiltak. Studier viser at ECT-behandling har fått en ny oppblomstring ved alvorlige lidelser, der andre metoder kommer til kort (5). De siste 20 årene er behandlingsmetoden blitt betydelig forbedret med tanke på sikkerhet og teknikk, inkludert rutinebruk av EKG- og EEG-monitorering. Det er hevdet at metoden bør brukes tidlig ved depresjoner som er livstruende og av psykotisk $\operatorname{grad}(6,7)$. Sterke kliniske prediktorer for respons er vrangforestillinger og psykomotorisk retardasjon hos alvorlig deprimerte (8). I Norge brukes ECT-behandling forholdsvis sjelden, men er i økende grad tatt i bruk de senere år. Oslo universitetssykehus, Ullevål, for eksempel, ga ved tusenårsskiftet slik behandling til ca. 20 pasienter per 100000 innbyggere mot bare tre i 1988 (9).

Flere studier har vist at elektrokonvulsiv behandling ved alvorlig depresjon gir en bedre og raskere respons enn antidepressiv legemiddelterapi (10). Hurtig respons er viktig ved høy selvmordsfare. De fleste behandlingsalgoritmer for depressive stemningslidelser anbefaler først minst to behandlingsforsøk med legemidler av 6-8 ukers varighet, med mulig unntak for livstruende depresjon. Spørsmålet er imidlertid om måneder med lidelse kan bli forkortet ved en tidligere innsettelse av ECT-behandling (11). På den annen side er det fortsatt usikkerhet knyttet til mulige varige bivirkninger. Selv om studiedesignen ikke kan dokumentere varige hukommelsesskader, besluttet vi å undersøke indikasjoner, registrert effekt, og mulige bivirkninger av ECT-behandling gitt gjennom 36 år ved Dikemark sykehus.

\section{Materiale og metode}

Dikemark var Norges største psykiatriske sykehus frem til omorganiseringen av Oslopsykiatrien i 1996. Sykehuset mottok voksne pasienter fra Oslo. Noen ble henvist direkte, mens andre ble søkt overflyttet fra psykiatriske klinikkavdelinger til videre behandling, dersom de ikke hadde oppnådd tilstrekkelig bedring. Ved tre avdelinger, hvorav en allmennpsykiatrisk og to alderspsykiatriske enheter, var det ført egne protokoller, og alle ECT-behandlinger ved disse avdelingene fra 1960 til og med 1995 er inkludert i materialet. I sykehusets øvrige fire avdelinger ble slik behandling gitt meget sjelden og her var ingen protokoller tilgjengelige.

Vi presenterer også data for andel av innlagte pasienter som mottok ECT-behandling i perioden 1955-59. Før 1960 ble det ikke ført protokoller, slik at tallene for årene 1955-59 er tatt ut av årsberetningene. Antallet pasienter innlagt ved sykehuset de ulike årene er tatt ut av sykehusets årsberetninger. Studien er naturalistisk og retrospektiv, og man har på bakgrunn av journalopplysningene vurdert nytten pasientene hadde de fire første ukene etter ECT-behandlingen. Undersøkelsen er et ledd i kvalitetssikringen.

Ved $80 \%$ av seriene ble det benyttet et Siemens-apparat med sinusbølgestimulering. Etter 1992 ble nye Thymatron-apparater med kortpulsstimulering benyttet. Behandlingene ble gitt tre ganger i uken. ECTprosedyren er beskrevet tidligere (9).

\section{Hovedbudskap}

- Pasientene som fikk elektrokonvulsiv terapi var i all hovedsak alvorlig deprimerte pasienter

- Terapien ga en rask og høy grad av respons ved alvorlige depresjoner

- Det var tendens til best respons ved psykotisk depresjon og høy alder

- Behandlingen ble godt tolerert, også hos somatisk dårlige eldre 
Vurdering av diagnose, behandlingseffekt og bivirkninger ble basert på førsteforfatters systematiske gjennomlesning av hele sykehusjournalen inkludert søknad, legenes notater, epikriser og miljøpersonalets daglige rapporter som ble skrevet minst tre ganger $i$ døgnet. Gjennom disse 36 årene ble ulike diagnosesystemer benyttet. Førsteforfatteren har rediagnostisert alle etter ICD-10. Standardiserte tester for bedring basert på Montgomery-Aasberg Depression Rating Scale (MADRS) er kun usystematisk benyttet fra ca. 1992, men symptomer, funksjonsbedring og kliniske vurderinger var beskrevet i den fortløpende journalen eller epikrisen. I alle journalene var den kliniske virkningen av den første serien vurdert og dokumentert. Kun i én journal var det ikke mulig å bedømme effekten av en senere serie.

Bedringen ble klassifisert på følgende måte:

- Mye bedret: gjenvinning av premorbid funksjonsnivå med full remisjon av symptomer og som førte til at pasienten ble utskrevet fra sykehuset innen fire uker.

- Bedret: bedring av symptomer og funksjonsnivå, men med restsymptomer som førte til at pasienten ikke kunne utskrives fra sykehuset i løpet av de første fire ukene.

- Uforandret: ingen bedring i klinisk tilstand eller funksjonsnivå.

- Forverret: forverring av symptomer eller funksjonsnivå innen fire uker etter behandlingen.

- Mye forverret: betydelig forverring av symptomer eller funksjonsnivå innen fire uker etter behandlingen.

Tidspunktet for de første bedringstegn som var notert i pasientens journal etter oppstart av ECT-behandlingen ble registrert. Likeså alle former for ubehag, bivirkninger eller komplikasjoner av behandlingen registrert de første fire ukene etter terapien.

Påliteligheten av diagnoser og skåringer av effekt og bivirkninger ble foretatt ved at 22 tilfeldige journaler ble trukket ut og gjennomgått uavhengig av medforfatteren. Det ble anvendt kappastatistikk. For diagnosene ble kappaverdien 0,84 (95\% KI 0,55-1,00). Vektet kappaverdi for effekt ble 0,64 (95\% KI 0,33-0,95). Kappaverdien for bivirkninger ble 0,83 (95\% KI 0,55-1,00).

Statistisk signifikante forskjeller er utregnet ved bruk av en tosidig Fisher-test. Statistisk signifikant forskjell ble definert som $p<0,05$.

Etikk

Studien er godkjent av personvernombudet ved Oslo universitetssykehus.

\section{Resultater}

Mellom 1960 og 1995 ble det gitt 241 behandlingsserier til 141 personer, gjennomsnittlig 1,7 serier til hver pasient. Totalt ble det gitt 1960 behandlinger, 8,1 behandlinger per serie i gjennomsnitt. I årene 1955-1959 fikk $7,7 \%$ av pasientene som ble innlagt ved

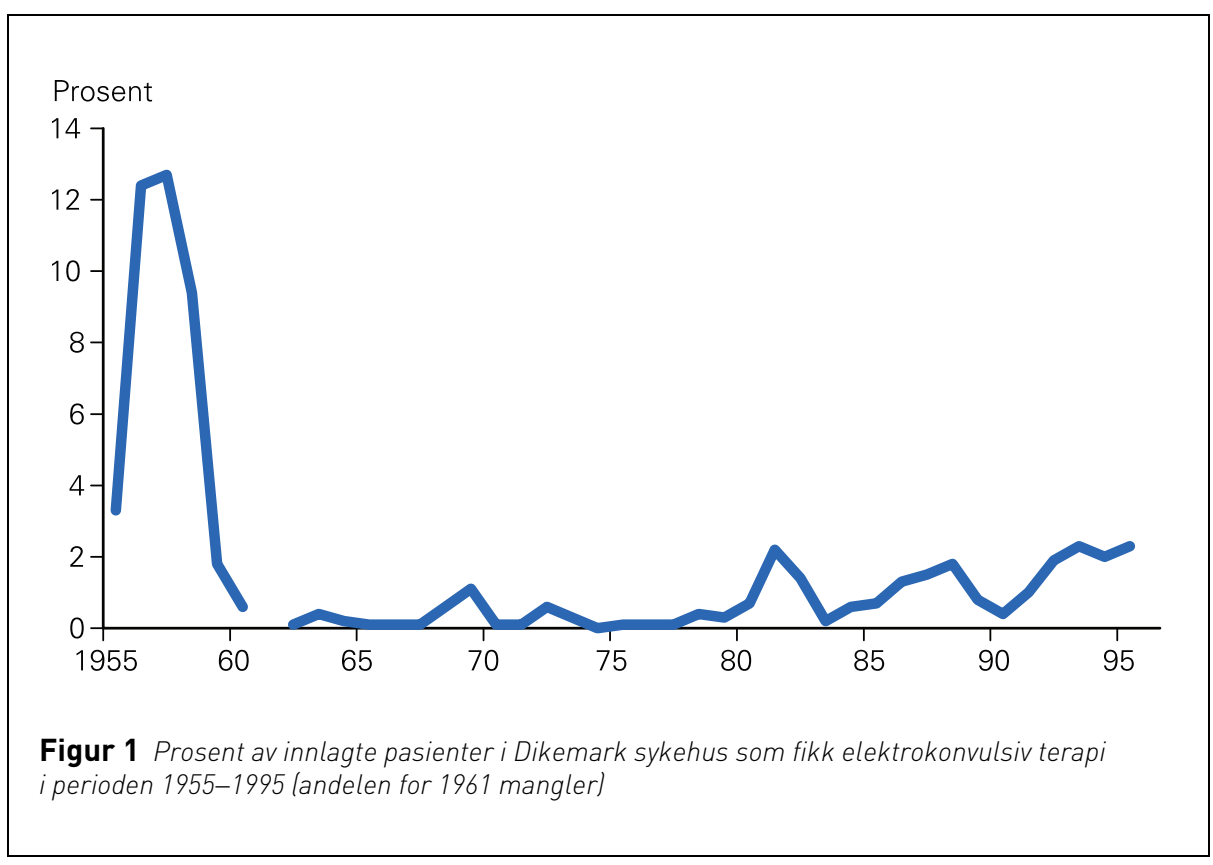

sykehuset slik terapi. I 1960-1979 ble behandlingen lite brukt, kun $0,3 \%$ av de innlagte fikk den. Fra 1980-1989 var bruken økende ved at 1,0\% fikk slik behandling, og $1,7 \%$ i årene 1990-95 (fig 1). 74\% var kvinner, $53 \%$ av alle var gift, $19 \%$ ugift, $17 \%$ enker/enkemenn og $9 \%$ var separert eller skilt. De fleste var i aldersgruppen 60-79 år ved sin første ECT-behandling. Aldersspredningen var 29-87 år, med et gjennomsnitt på 64 år $(\mathrm{SD}=10,9)$. Gjennomsnittsalderen ved første depressive episode var 52 år (4-85 år). Av 124 med alvorlig depresjon som hoveddiagnose hadde 93 (75\%) depresjon av psykotisk type. Hos 136 pasienter (96\%) ble det registrert minst én komorbid somatisk lidelse. Disse hadde gjennomsnittlig 4,8 komorbide somatiske lidelser i tillegg til depresjonen. Kardiovaskulære, urogenitale og muskel- og skjelettrelaterte lidelser var de hyppigste (tab 1).

Kun 12 pasienter (9\%) var førstegangsinnlagt. En tredel hadde mer enn fem tidligere innleggelser i psykiatrisk avdeling. Av alle hadde $129(91 \%)$ fors $ø \mathrm{kt}$ antidepressive legemidler gjennom lengre tid. 107 (76\%) hadde brukt minst to ulike antidepressiver, og $67(48 \%)$ fra minst to ulike klasser, og 31 $(22 \%)$ hadde forsøkt litium alene eller i kombinasjon. I alt $52(37 \%)$ hadde fått ECTbehandling tidligere.

Resultatet av den første ECT-serien ( $n=141$ )

Tabell 2 viser at hos $14 \%$ var tilstanden uforandret, mens $85 \%$ ble bedre i løpet av de fire første ukene etter første ECT-serie.

Tabell 3 viser registrert effekt hos pasienter med ulike diagnoser. De fleste hadde tilbakevendende alvorlige depresjoner med vrangforestillinger og selvmordsfare. I alt $64(45 \%)$ hadde foretatt minst ett selvmordsforsøk. Ni hadde en hjerneorganisk hoveddiagnose, mens fem hadde schizofreni
Tabell 1 Antall pasienter med somatiske komorbide sykdommer $(\%)(n=141)$

\begin{tabular}{lcc} 
& Antall & $(\%)$ \\
\hline Kardiovaskulære & 77 & $(54,6)$ \\
\hline $\begin{array}{l}\text { Muskel- og skjelett- } \\
\text { relaterte }\end{array}$ & 74 & $(52,5)$ \\
Urogenitale & 71 & $(50,4)$ \\
\hline Gastrointestinale & 46 & $(32,6)$ \\
\hline Respiratoriske & 44 & $(31,2)$ \\
\hline Knyttet til nervesystemet & 42 & $(29,8)$ \\
\hline Endokrine & 32 & $(22,7)$ \\
\hline Knyttet til sanseorganer & 31 & $(22,0)$ \\
\hline Hudrelaterte & 31 & $(22,0)$ \\
\hline Hematologiske & 16 & $(11,3)$ \\
\hline Allergiske & 7 & $(5,0)$ \\
\hline Andre & 3 & $(2,1)$ \\
\hline Lever & 2 & $(1,4)$ \\
& &
\end{tabular}

Tabell 2 Effekt av elektrokonvulsiv terapi registrert i løpet av de fire første ukene etter første og senere behandlingsserier ved Dikemark sykehus 1960-95 $(n=241)$

\begin{tabular}{lrrrrr} 
& \multicolumn{2}{c}{$\begin{array}{c}\text { Første serie } \\
\text { Antall }\end{array}$} & \multicolumn{3}{c}{ Senere serier } \\
& $\begin{array}{c}\text { Antall } \\
\text { pasien- } \\
\text { ter }\end{array}$ & $(\%)$ & $\begin{array}{c}\text { Ansien- } \\
\text { ter }\end{array}$ & $(\%)$ \\
\hline Mye bedret & 61 & $(43,3)$ & 39 & $(39)$ \\
\hline Bedret & 59 & $(41,8)$ & 48 & $(48)$ \\
\hline Uforandret & 20 & $(14,2)$ & 9 & $(9)$ \\
\hline Forverret & 1 & $(0,7)$ & 3 & $(3)$ \\
\hline $\begin{array}{l}\text { Mye for- } \\
\text { verret }\end{array}$ & 0 & - & 0 & - \\
\hline Ukjent & 0 & - & 1 & $(1)$ \\
\hline Totalt & 141 & $(100)$ & 100 & $(100)$
\end{tabular}


Tabell 3 Effekt av elektrokonvulsiv terapi ved ulike diagnoser registrert i løpet av de fire første ukene etter behandling ved Dikemark sykehus 1960-95 $(n=141)$

$\begin{array}{ccccc}\begin{array}{c}\text { Alvorlig } \\ \text { depresjon } \\ \text { med } \\ \text { psykose }\end{array} & \begin{array}{c}\text { Alvorlig } \\ \text { depresjon } \\ \text { uten } \\ \text { psykose }\end{array} & \begin{array}{c}\text { Hjerne- } \\ \text { organisk }\end{array} & \begin{array}{c}\text { Schizofreni/ } \\ \text { schizo- } \\ \text { affektiv }\end{array} & \text { Totalt } \\ \text { Antall (\%) } & \text { Antall (\%) } & \text { Antall (\%) } & \text { Antall (\%) } & \text { Antall (\%) }\end{array}$

Bedret/

mye bedret

Uforandret

84 (90)

8

Forverret/

mye forverret

Totalt

$-$

$23 \quad(74)$

74) 5

(56)$$
8
$$

120

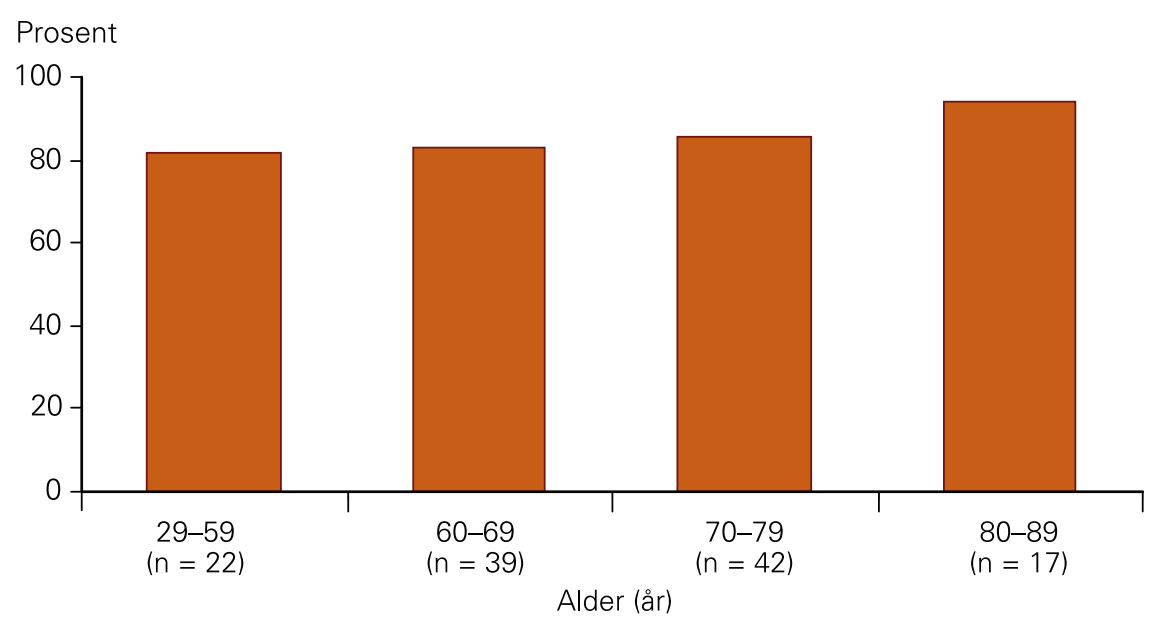

Figur 2 Andel av pasientene som ble vurdert som bedret i ulike aldersgrupper fire uker etter første ECT-serie ved Dikemark sykehus 1960-95 ( $n=120$ )

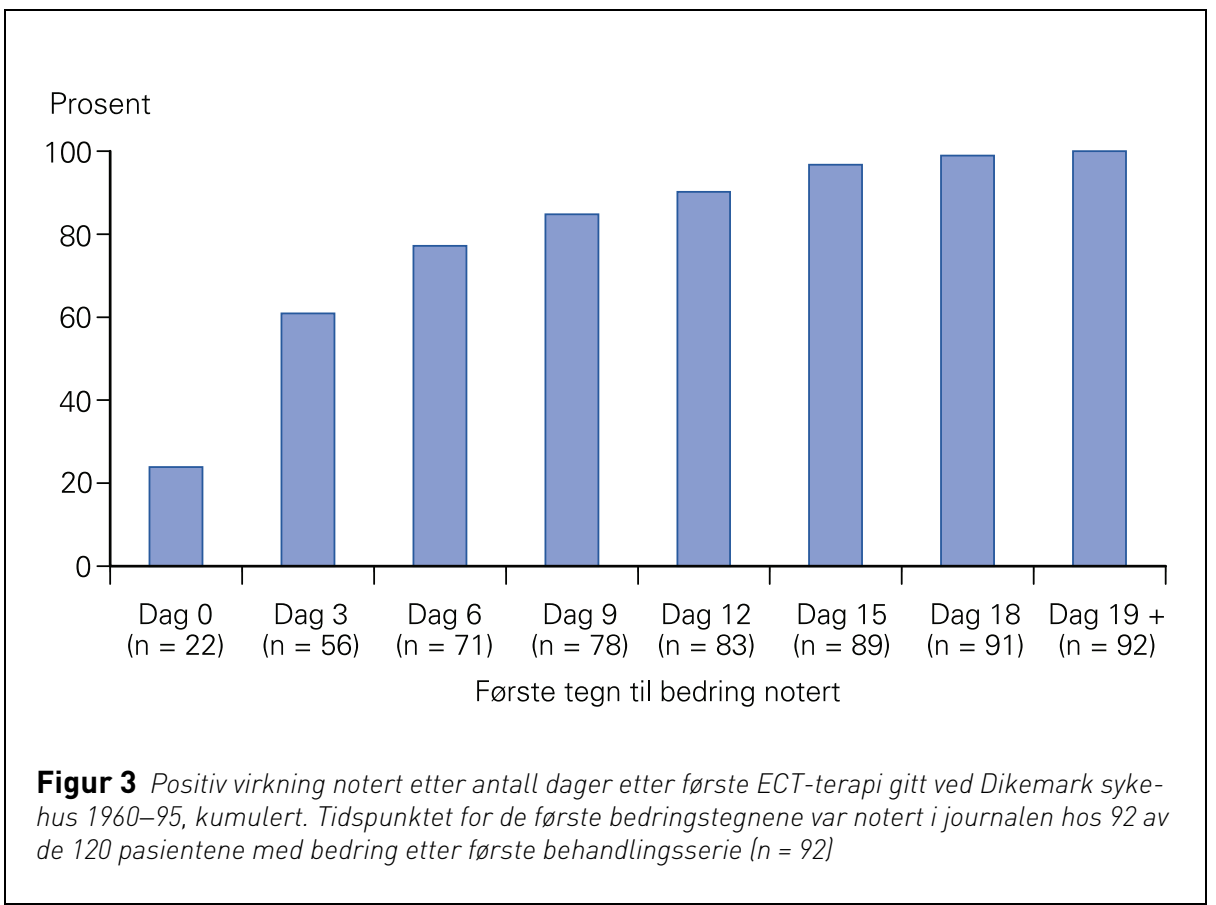

og tre schizoaffektiv lidelse. Hos disse 17 var alvorlig depresjon indikasjonen for ECT-behandlingen. $30(21 \%)$ hadde bipolar depresjon. Av de 124 med affektiv hovedlidelse hadde $93(75 \%)$ psykose, kategorisert som F31.50, F32.30 og F33.30 i ICD-10. I denne gruppen ble tilstanden hos $84(90 \%)$ registrert som bedret. Alle åtte pasienter med depresjon ved schizofreni eller schizoaffektiv lidelse (F20-25.2) ble bedre, hvorav tre ble registrert som mye bedre.

Figur 2 viser registrert effekt de første fire ukene etter behandling for ulike aldersgrupper med tendens til best effekt hos de eldste.

\section{Hvor raskt inntraff bedringen}

etter første ECT-behandling?

Hos 92 av de 120 pasientene $(77 \%)$ med bedring etter første ECT-serie var tidspunktet for de første bedringstegnene notert i journalen. Hos $24 \%$ var de første bedringstegnene notert samme dag som første behandling ble gitt (dag 0), innen seks dager hos $77 \%$ og innen 15 dager hos $97 \%$ (fig 3).

Allerede etter tre behandlinger ble det registrert bedringstegn hos de fleste pasientene uavhengig av diagnose. Det ble ikke funnet noen statistisk signifikant sammenheng mellom stimulustype (sinusbølgebehandling eller kortpulsstimulering) eller elektrodeplassering og hvor raskt effekten inntraff (data ikke vist).

Resultatet av alle ECT-seriene ( $n=241$ )

Av 241 ECT-serier var det mulig å vurdere bedringsgrad for 240. Funnene ved senere serier var omtrent de samme som ved første serie (tab 2).

I halvparten av seriene ble det observert bivirkninger i forbindelse med behandlingen (tab 4). De fleste var meget kortvarige og kun til stede i oppvåkningsfasen etter narkosen. Glemsomhet ble notert hos 49 (20\%), forvirring hos 34 (14\%), svimmelhet/ustøhet hos $14(6 \%)$ og hodepine hos $8(3 \%)$.

\section{Diskusjon}

Indikasjonen for elektrokonvulsiv behandling ved Dikemark sykehus etter 1960 gjenspeiler dagens anbefalinger med relativt snevre indikasjoner. Hele $88 \%$ hadde en affektiv hovedlidelse, og de var i høy grad belastet med alvorlig depresjon av psykotisk grad, stor somatisk sykelighet og hadde hatt mange selvmordsforsøk og innleggelser før første behandlingsserie.

Om lag $85 \%$ ble rapportert som bedre i løpet av fire uker etter behandlingsstart, og de fleste av disse viste bedringstegn allerede den første uken av behandlingen. Dette gjaldt både $\mathrm{i}$ forbindelse med den første og de senere seriene. Totalt ble $43 \%$ beskrevet som mye bedre etter første ECT-serie og kunne utskrives innen fire uker. Dette er en høy responsrate hos pasienter som i stor grad kan betegnes som behandlingsresistente.

I en prospektiv studie i USA oppnådde $75 \%$ av 253 pasienter med alvorlig unipolar depresjon som fullførte studien remisjon et- 
ter behandlingen. Blant dem med psykotiske symptomer oppnådde hele $95 \%$ remisjon med bitemporal elektrodeplassering (8). Psykose hos pasienter med alvorlig depresjon synes å være en prediktor for gunstig utbytte av bitemporal ECT-behandling, mens antidepressiver antakelig er mindre effektive $(10,12)$. Psykotisk deprimerte pasienter bør derfor ikke bli betegnet som behandlingsresistente før de har fătt en full ECT-serie. Behandlingen kan ifølge en lederartikkel av Beale \& Kellner spare lidelse når den gis tidligere i forløpet av psykotisk depresjon (13). En lengre indeksepisode reduserer muligheten for å oppnå remisjon (7). Kellner og medarbeidere fant at elektrokonvulsiv terapi reduserte selvmordfaren med $81 \%$ i løpet av ti behandlinger (14). Tidlig bruk av slik behandling forbindes med redusert liggetid $\mathrm{i}$ sykehus og mindre kostnader (15).

Behandlingsresultatet er overraskende godt siden de aller fleste hadde forsøkt to antidepressiver gjennom lengre tid. I STAR*Dstudien i USA oppnådde kun $14 \%$ remisjon ved tredje behandlingsforsøk med legemidler av dem som ikke hadde oppnådd remisjon etter bruk av to ulike typer antidepressiv behandling (11).

De fleste pasientene viste bedringstegn allerede i forste uke. Hurtig respons ved dype depresjoner er også funnet av andre (16). ECT-behandling bør være førstevalg når det er viktig med rask remisjon. Dette gjelder pasienter med stort lidelsestrykk, alvorlig selvmordsfare, depressive psykoser, melankoli, livstruende depresjon med insomni, spisevegring og signifikant vekttap (11). Dette gjelder også enkelte med alvorlig depresjon under graviditet og etter fødsel $(5,17)$.

Elektrokonvulsiv terapi ble godt tolerert I nesten halvparten av journalene hadde verken lege eller sykepleier notert noen form for bivirkninger eller komplikasjoner. Hos dem med glemsomhet ble hukommelsesreduksjonen beskrevet som betydelig etter sju serier $(3 \%)$. Varigheten av erindringssvikten kjenner vi ikke. Fra andre studier vet vi at disse bivirkningene forsvinner etter få uker hos de aller fleste, hos andre etter noen måneder. Man kan ikke kategorisk si at hukommelsessvekkelsen forsvinner hos alle (4). Svekkelsen kan også skyldes selve depresjonen. Lerer og medarbeidere konkluderte med at to behandlinger i uken gir god effekt med færre kognitive bivirkninger enn ved tre behandlinger i uken, mens tre behandlinger $\mathrm{i}$ uken er indisert når hurtig innsettende bedring er viktig (18). Vi vet at bivirkninger reduseres ved kortpulsstimulering og unilateral elektrodeplassering som er standard nå (19). Eldre med kognitiv svikt får oftere kortvarige forvirringsepisoder umiddelbart etter behandlingen, noe som er avhengig av antall behandlinger, energi og hvilken stimuleringstype de får (20). Etter vår erfaring letner hodepinen gjerne etter det første måltidet eller den kan behandles med et mildt smertestillende legemiddel.
I de fleste tilfellene var bivirkningene forbigående. Fem pasienter fikk alvorlige og mer varige komplikasjoner i tilslutning til behandlingen (mulig kompresjonsfraktur, lårhalsfraktur, pareser og hjerteinfarkt/død). Legene vurderte at flere av hendelsene ikke hadde direkte relasjon til ECT-behandlingen.

Å gå med en alvorlig depresjon over tid er i seg selv helsefarlig, med økt fare for morbiditet og mortalitet. Risikoen for bivirkninger av behandlingen må vurderes opp mot risikoen ved å ha en slik lidelse. I en stor registerbasert studie ble det funnet en redusert dødelighet av naturlige årsaker og lett økt selvmordsrate hos de hospitaliserte pasienter som hadde fått ECT-behandling sammenliknet med dem som ikke hadde fătt det. De pasientene som hadde fătt slik terapi var psykisk og somatisk alvorlig syke, og redusert dødelighet av naturlige årsaker ble tatt til inntekt for at behandlingen ikke var farlig, men forfatterne antar at effekten på den psykiske helsen reduserte dødeligheten av somatiske årsaker. En viss økt selvmordsfare i denne gruppen ble antatt å skyldes et spesielt utvalg med stor grad av sykelighet, men viser også at spesiell årvåkenhet hos behandlerne er nødvendig etter behandlingen med vurdering av vedlikeholdsbehandling, for eksempel med antidepressiver (21).

\section{Styrker og svakheter}

Pasientpopulasjonen besto av sektorinnlagte pasienter og dårlig fungerende pasienter overført fra andre avdelinger. Populasjonen kan dermed representere noe dårligere fungerende pasienter enn på landsbasis.

Viktige begrensninger i denne studien er først og fremst den retrospektive designen og avhengigheten av journalopplysningenes kvalitet. Studien kan ikke gi svar på om noen har fått langtidsskade på hukommelsen. Vurdering av klinisk effekt er gjort av samme person, førsteforfatter, etter gjennomlesning av journalene. Førsteforfatter har arbeidet ved alle tre avdelingene, og har vært med og gitt noen av ECT-behandlingene. Det kan svekke validiteten av vurderingene. Reliabilitet av diagnoser, effekt og bivirkninger ble kontrollert ved uavhengig gjennomgang av tilfeldig utvalgte journaler av andreforfatter og tyder på at vurderingene er nøkterne. Resultatene er ikke sammenliknet med en kontrollgruppe som fikk en annen type behandling ved sykehuset i samme periode. Imidlertid er styrken av studien dens naturalistiske design $i$ et psykiatrisk sykehus som brukte ECT-behandling i begrenset utstrekning, noe som sannsynligvis reflekterer en typisk norsk klinisk praksis i denne tidsperioden. Samtlige pasienter som mottok denne type behandling gjennom 36 år ved tre avdelinger ved Dikemark sykehus er med. Journalene var fyldige, og rapportene fra syke- og hjelpepleierne som ble skrevet fortløpende flere ganger i løpet av døgnet, var detaljerte. En fremtidig studie bør klargjøre forskjeller i respons mellom ulike behandlingsmetoder ved å bruke
Tabell 4 Bivirkninger beskrevet de første fire uker etter elektrokonvulsiv terapi gitt ved Dikemark sykehus 1960-95 ( $\mathrm{n}=241$ )

\begin{tabular}{|lrc|} 
& $\begin{array}{c}\text { Antall } \\
\text { serier }\end{array}$ & $(\%)$ \\
\hline Intet notert & 118 & $(49,0)$ \\
\hline Glemsomhet & 42 & $(17,4)$ \\
\hline Betydelig glemsomhet & 7 & $(2,9)$ \\
\hline Forvirring & 34 & $(14,1)$ \\
\hline Svimmelhet/ustøhet & 14 & $(5,8)$ \\
\hline Hodepine $^{\prime}$ & 8 & $(3,3)$ \\
\hline Kardiovaskulære $^{1}$ & 5 & $(2,1)$ \\
\hline Nevrologiske $^{2}$ & 3 & $(1,2)$ \\
\hline Annet $^{3}$ & 10 & $(4,1)$ \\
\hline Totalt $^{2}$ & 241 & $(100)$
\end{tabular}

${ }^{1}$ Forbigående synkope på grunn av ortostatisk hypo tensjon, forbigående atrieflimmer, hemiparese og hjerteinfarkt/død. Legene mente at de alvorlige hendelsene (hemiparese og hjerteinfarkt/død) skjedde uavhengig av gjennomført ECT-behandling Parese (med påfølgende funn av underliggende kreftsykdom), forbigående droppfot,og forbigående nedsatt følelse i to fingertupper

${ }^{3}$ Mulig kompresjonsfraktur, lårhalsfraktur, reoperasjon etter hoftebrudd, brukket tann, kvalme, forbigående økte leverenzymverdier og forbigående hypoman

anbefalte vurderingsskalaer og uavhengige personer for å vurdere effekt og bivirkninger.

\section{Konklusjon}

Resultatene tyder på at ECT-terapi er en metode med rask respons ved behandling av alvorlig depresjon. Behandlingen ble relativt godt tolerert, selv av fysisk skrøpelige eldre. Den raskt inntredende effekten er av stor betydning der lidelsestrykket eller selvmordsfaren er stor.

Oppgitte interessekonflikter: Ingen

Vi takker Ole Klungsøyr for statistisk hjelp.

\section{Litteratur}

. Fink M, Taylor MA. Electroconvulsive therapy: evidence and challenges. JAMA 2007: 298: 330-2.

2. Nordanskog P, Dahlstrand U, Larsson MR et al. Increase in hippocampal volume after electroconvulsive therapy in patients with depression: a volumetric magnetic resonance imaging study. J ECT 2010; 26: 62-7

3. Lisanby SH, Maddox JH, Prudic J et al. The effects of electroconvulsive therapy on memory of autobiographical and public events. Arch Gen Psychiatry 2000; 57: 581-90.

4. Sackeim HA, Prudic J, Fuller R et al. The cognitive effects of electroconvulsive therapy in community settings. Neuropsychopharmacology 2007; 32: 244-54.

5 McCall WV. Electroconvulsive therapy in the era of modern psychopharmacology. Int J Neuropsychopharmacol 2001; 4: 315-24.

American Psychiatric Association Committee on Electroconvulsive Therapy. The practice of electroconvulsive therapy. Recommendations for treatment, training, and privileging. 2. utg. Washington D.C.: American Psychiatric Association, 2001

Kho KH, Zwinderman AH, Blansjaar BA. Predictors for the efficacy of electroconvulsive therapy: chart review of a naturalistic study. J Clin Psychiatry 2005; 66: 894-9. 
8. Petrides G, Fink M, Husain MM et al. ECT remission rates in psychotic versus nonpsychotic depressed patients: a report from CORE. J ECT 2001; 17: 244-53.

9. Moksnes KM, Vatnaland T, Eri B et al. Elektrokonvulsiv terapi i Ullevål sektor i Oslo 1988-2002. Tidsskr Nor Lægeforen 2006; 126: 1750-3.

10. Pagnin D, de Queiroz V, Pini S et al. Efficacy of ECT in depression: a meta-analytic review. J ECT 2004: 20: $13-20$.

11. McCall WV. What does Star*D tell us about ECT? J ECT 2007; 23: 1-2.

12. Kho KH, van Vreeswijk MF, Simpson S et al. A meta-analysis of electroconvulsive therapy efficacy in depression. J ECT 2003; 19: 139-47.

13. Beale MD, Kellner CH. ECT in treatment algorithms: no need to save the best for last. J ECT 2000; 16: 1-2.

14. Kellner $\mathrm{CH}$, Fink M, Knapp R et al. Relief of expressed suicidal intent by ECT: a consortium for research in ECT study. Am J Psychiatry 2005; 162: 977-82.

15. Markowitz J, Brown R, Sweeney J et al. Reduced length and cost of hospital stay for major depression in patients treated with ECT. Am J Psychiatry 1987; 144: 1025-9.
16. Kho KH, Blansjaar BA, Vothknecht S et al. A study into predictors for the speed of response to electroconvulsive therapy. J ECT 2004; 20: 154-9.

17. Berle JØ. Alvorlig depresjon og psykose post partum - når bør elektrokonvulsiv behandling brukes? Tidsskr Nor Lægeforen 1999; 119: 3000-3.

18. Lerer B, Shapira B, Calev A et al. Antidepressant and cognitive effects of twice- versus three-timesweekly ECT. Am J Psychiatry 1995; 152: 564-70.

19. Fraser LM, O'Carroll RE, Ebmeier KP. The effect of electroconvulsive therapy on autobiographical memory: a systematic review. J ECT 2008; 24 : $10-7$

20. Kelly KG, Zisselman M. Update on electroconvulsive therapy (ECT) in older adults. J Am Geriatr Soc 2000; 48: 560-6.

21. Munk-Olsen T, Laursen TM, Videbech P et al. Allcause mortality among recipients of electroconvulsive therapy: register-based cohort study. $\mathrm{Br}$ J Psychiatry 2007; 190: 435-9.

Mottatt 15.9. 2009, første revisjon innsendt 7.12. 2009, godkjent 23.9. 2010. Medisinsk redaktør Siri Lunde. 